\title{
Activation of Extracellular Signal-Regulated Kinase by Stretch-Induced Injury in Astrocytes Involves Extracellular ATP and P2 Purinergic Receptors
}

\author{
Joseph T. Neary, ${ }^{1}$ Yuan Kang, ${ }^{1}$ Karen A. Willoughby, ${ }^{2}$ and Earl F. Ellis ${ }^{2}$ \\ ${ }^{1}$ Research Service, Veterans Affairs Medical Center, Department of Pathology and Department of Biochemistry and Molecular Biology, and Neuroscience \\ Program, University of Miami School of Medicine, Miami, Florida 33125, and ²Department of Pharmacology and Toxicology, School of Medicine, Virginia \\ Commonwealth University, Richmond, Virginia 23298
}

Gliosis is characterized by hypertrophic and hyperplastic responses of astrocytes to brain injury. To determine whether injury of astrocytes produced by an in vitro model of brain trauma activates extracellular signal-regulated protein kinase (ERK), a key regulator of cellular proliferation and differentiation, astrocytes cultured on deformable SILASTIC membranes were subjected to rapid, reversible strain (stretch)-induced injury. Activation of ERK was observed $1 \mathrm{~min}$ after injury, was maximal from 10 to $30 \mathrm{~min}$, and remained elevated for $3 \mathrm{hr}$. Activation of ERK was dependent on the rate and magnitude of injury; maximum ERK activation was observed after a 20 - 60 $\mathrm{msec}, 7.5 \mathrm{~mm}$ membrane displacement. ERK activation was blocked by inhibiting MEK, the upstream activator of ERK. Activation of ERK was reduced when calcium influx was diminished. When extracellular ATP was hydrolyzed by apyrase or ATP/P2 receptors were blocked, injury-induced ERK activation was significantly reduced. P2 receptor antagonist studies indicated a role for P2X2 and P2Y1, but not $\mathrm{P} 2 \mathrm{X} 1, \mathrm{P} 2 \mathrm{X} 3$, or P2X7, receptors in injury-induced ERK activation. These findings demonstrate for the first time that ATP released by mechanical injury is one of the signals that triggers ERK activation and suggest a role for extracellular ATP, P2 purinergic receptors, and calcium-dependent ERK signaling in the astrocytic response to brain trauma.

Key words: purinergic receptor; ERK; astrocyte; extracellular ATP; calcium; trauma; brain injury; glia; gliosis; mechanical stretch

\section{Introduction}

Traumatic brain injury leads to the development of gliosis, but little is known about the signal transduction mechanisms that underlie this process. Gliosis is characterized by hypertrophic and hyperplastic changes of astrocytes in response to brain injury. Because cellular proliferation and differentiation are mediated by extracellular signal-regulated protein kinase (ERK), a member of the mitogen-activated protein kinase (MAPK) family, we hypothesized that trauma would activate ERK in astrocytes. To test this hypothesis, we used a well characterized in vitro model of brain trauma (Ellis et al., 1995). In this model, cells are grown on SILASTIC membranes that deform when subjected to a pulse of compressed gas. The extent and duration of strain or "stretch" can be precisely controlled by means of a pressure regulator and timer. Tissue strain is an important component of in vivo brain injury and is associated with the production of diffuse axonal injury (Marguiles et al., 1990; Thibault et al., 1992). The in vitro model of stretch injury used here has been validated by demonstrating that it produces many of the post-traumatic responses observed in vivo, including intracellular lesions to mitochondria, Golgi, and cytoskeletal elements in astrocytes and neurons (Die-

Received 0ct. 28, 2002; revised Dec. 27, 2002; accepted Dec. 30, 2002.

This work was supported by the Department of Veterans Affairs (J.T.N.) and National Institutes of Health Grant NS-27214 (E.F.E.). We are grateful to You-fang Shi for preparation of astrocyte cultures and to Sallie Holt for assistance with preparation of this manuscript.

Correspondence should be addressed to Dr. Joseph T. Neary, Research Service 151, Veterans Affairs Medical Center, 1201 Northwest 16th Street, Miami, FL 33125. E-mail: jneary@med.miami.edu.

Copyright $\odot 2003$ Society for Neuroscience $\quad 0270-6474 / 03 / 232348-09 \$ 15.00 / 0$ trich et al., 1994; Ellis et al., 1995; McKinney et al., 1996), increased total cell calcium in astrocytes (Hovda et al., 1992; Fineman et al., 1993; Rzigalinski et al., 1997), transient increases in intracellular free calcium concentration (Rzigalinski et al., 1998), activation of phospholipases (Wei et al., 1982; Lamb et al., 1997; Floyd et al., 2001), free radical formation (McKinney et al., 1996; Lamb et al., 1997), and depletion and release of intracellular ATP (Ahmed et al., 2000). In addition, voltage-dependent $\mathrm{Mg}^{2+}$ blockade of the NMDA current was reduced in mechanically stretched neurons (Zhang et al., 1996), a finding that is consistent with the observation that $\mathrm{Mg}^{2+}$ reduces the severity of neuronal injury induced by NMDA and traumatic brain injury (McIntosh, 1992).

ATP is released from injured cells (Bodin et al., 1992; Bergfeld and Forrester, 1992), including astrocytes (Ahmed et al., 2000). After addition of ATP, cultured astrocytes develop characteristics of gliosis (Rathbone et al., 1992; Neary and Norenberg, 1992; Neary et al., 1994a,b, 1998; Abbracchio et al., 1994; Bolego et al., 1997), and injection of an ATP analog into rat brain causes a hypertrophic and hyperplastic response in astrocytes similar to that observed after brain injury (Franke et al., 1999). Extracellular ATP stimulates ERK in astrocytes by a signaling process mediated by P2 purinergic receptors (Neary and Zhu, 1994; King et al., 1996; Neary et al., 1999). Because ERK activity in astrocytes is stimulated by extracellular ATP and because ATP is released from astrocytes after stretch-induced injury, we postulated that the released ATP could activate ERK. We now report that ERK is rapidly activated after stretch-induced injury of cultured astrocytes by a calcium-dependent pathway and that release of ATP 
after injury contributes to the activation of ERK by stimulating specific subtypes of $\mathrm{P} 2 \mathrm{X}$ and $\mathrm{P} 2 \mathrm{Y}$ purinergic receptors.

\section{Materials and Methods}

Cell culture and treatment. Primary astrocytes were obtained from neonatal rat (Fischer) cerebral cortices as previously described (Neary et al., 1994b). Cells were seeded in six-well tissue culture Flex Plates that have well bottoms made of SILASTIC membranes that are coated with collagen (Flexcell International, McKeesport, PA). Cells were seeded at a density of 400,000 cells per well; cells were not replated before use. At least $99 \%$ of the cell population were astrocytes, as determined by staining with cell-specific markers (Neary et al., 1994b). Experiments were conducted with 3- to 6-week-old cultures. Before stretch-induced injury, cells which had been maintained in DMEM containing $10 \%$ horse serum were shifted to the quiescent phase by incubation in DMEM containing $0.5 \%$ horse serum for $48-72 \mathrm{hr}$. Stock solutions of nucleotides were divided into single-use aliquots and stored at $-80^{\circ} \mathrm{C}$.

Stretch-induced injury. Confluent cultures of astrocytes grown in Flex Plates were subjected to injury by means of a model 94A Cell Injury Controller (Virginia Commonwealth University, Richmond, VA), a device that regulates a pulse of compressed gas to rapidly and transiently deform the SILASTIC membrane and adherent cells in a manner such that the magnitude and duration of the injury can be controlled (Ellis et al., 1995). Before each experiment, the injury controller device was calibrated as described by the manufacturer. The duration of the pressure pulse was varied from 20 to $99 \mathrm{msec}$, and the degree of SILASTIC membrane displacement studied ranged from 3 to $7.5 \mathrm{~mm}$ ( $8-54 \%$ stretch). These parameters are within the range of mild, moderate, and severe stretch, as previously defined by studies with this in vitro stretch injury model (Ahmed et al., 2000). This range of membrane deformations corresponds to biaxial strains, or stretch, that are relevant to those that occur in humans after rotational acceleration-deceleration injury, as indicated by studies with gel-filled human skulls (Shreiber et al., 1995). Care was taken to avoid excessive handling of the Flex plates to minimize release of ATP caused by fluid flow and perturbation of the SILASTIC membranes, which can lead to higher values of ERK activity in uninjured cells than those reported here.

ERK activity measurements. After injury for the duration and extent of displacement indicated, cells were rinsed twice quickly in ice-cold Dulbecco's PBS and lysed in a buffer containing $20 \mathrm{~mm}$ Tris, pH 7.0, 0.27 M sucrose, $1 \mathrm{~mm}$ EDTA, $1 \mathrm{~mm}$ EGTA, $50 \mathrm{~mm} \mathrm{NaF}, 1 \mathrm{~mm}$ dithiothreitol (DTT), $1 \mathrm{~mm}$ sodium orthovanadate, $10 \mathrm{~mm}$ sodium $\beta$-glycerophosphate, $5 \mathrm{~mm}$ sodium pyrophosphate, $100 \mu \mathrm{g} / \mathrm{ml} 4$-(2-aminoethyl) benzenesulfonylfluoride (AEBSF), $0.3 \mathrm{U} / \mathrm{ml}$ aprotinin, $1 \mu \mathrm{g} / \mathrm{ml}$ pepstatin A, $4 \mu \mathrm{M}$ leupeptin, and 1\% Triton X-100. For the apyrase experiments, cells were rinsed an additional three times in ice-cold PBS to ensure removal of apyrase before conducting ERK activity assays. The lysates were centrifuged in a microfuge for $5 \mathrm{~min}$ at $4^{\circ} \mathrm{C}$. ERK activity was measured in duplicate as previously described (Neary and Zhu, 1994) with the modification that a highly selective peptide substrate (Amersham Biosciences, Piscataway, NJ) was used instead of myelin basic protein. In brief, aliquots ( $15 \mu \mathrm{l}$ containing $3-6 \mu \mathrm{g}$ protein) of the lysate supernatants were assayed at $30^{\circ} \mathrm{C}$ for $30 \mathrm{~min}$ in a final reaction solution containing $0.2 \mathrm{~mm}$ ATP $\left(0.4 \mu \mathrm{Ci}\left[\gamma^{32} \mathrm{P}\right] \mathrm{ATP} ; 3000 \mathrm{Ci} / \mathrm{mmol}\right.$; PerkinElmer Life Sciences/NEN, Boston, MA), $0.2 \mathrm{~mm} \mathrm{MgCl}_{2}$, and peptide substrate in a final volume of $30 \mu \mathrm{l}$, according to the manufacturer's instructions. Under these conditions, the reaction is linear with respect to time and enzyme concentration. Reactions were terminated by adding $10 \mu \mathrm{l}$ stop solution. Aliquots $(30 \mu \mathrm{l})$ were pipetted onto strips of phosphocellulose paper (Sevetson et al., 1993) that were washed twice in $75 \mathrm{~mm}$ phosphoric acid for $2 \mathrm{~min}$ and twice in water for $2 \mathrm{~min}$. Strips were dried, transferred to scintillation vials, and radioactivity was assessed by liquid scintillation counting. ERK activity was expressed as picomoles of phosphate transferred per minute per milligram of protein. Protein concentrations were determined by the modified Lowry procedure as described (Peterson, 1983) with bovine serum albumin (BSA) as standard. ERK activities in injured samples were normalized and expressed as fold stimulation by comparing these values to those obtained from control, uninjured samples from the same experiment conducted on the same Flex plate. The peptide substrate used in the ERK activity assay is based on the Thr669 phosphorylation site of the EGF receptor. This substrate is much more specific for ERK1/2 than the previously used myelin basic protein that contains phosphorylation sites recognized by PKC and PKA. Although the phosphorylation site in the peptide substrate is also recognized by the cell cycle-dependent enzyme p34cdc2 kinase, the activity of this enzyme is minimal in quiescent cells and active at the G2/M phase transition. Because our ERK activity studies have been conducted in quiescent astrocytes and at earlier time points than the G2/M phase transition, p34cdc2 kinase does not contribute appreciably to the activity observed in our studies. In accord with this, results of activity measurements using this peptide substrate were in good agreement with those obtained by measurement of phosphorylated ERK1/2 as described below.

Immunoblotting. Samples containing equal amounts of protein were subjected to SDS-polyacrylamide gel electrophoresis (Laemmli, 1970) using $11 \%$ acrylamide and transferred to nitrocellulose filters with a Genie electrophoretic blotter (Idea Scientific, Minneapolis, MN) for $1 \mathrm{hr}$ at $12 \mathrm{~V}$ in a transfer buffer containing $25 \mathrm{~mm}$ Tris, $192 \mathrm{~mm}$ glycine, and $20 \%$ methanol. Filters were incubated with a blocking solution containing $20 \mathrm{~mm}$ Tris, pH 7.7, $137 \mathrm{~mm} \mathrm{NaCl}, 0.1 \%$ Tween 20 (TTBS), and 5\% nonfat dry milk for $1 \mathrm{hr}$ at room temperature, rinsed in TTBS, and then incubated for $1 \mathrm{hr}$ at room temperature with specific antibodies diluted in TTBS containing 5\% BSA [monoclonal antibodies recognizing dually phosphorylated ERK1/2 (Thr183, Tyr185) (1:2000; Cell Signaling Technology, Beverly, MA) or polyclonal antibodies raised against ERK1/2 (1:5000; Santa Cruz Biotechnology, Santa Cruz, CA)]. After three rinses in TTBS, filters were incubated for $1 \mathrm{hr}$ at room temperature with horseradish peroxidase-conjugated anti-mouse or anti-rabbit IgG diluted in TTBS (1:10,000 dilution; Amersham Biosciences). Phospho- and total ERK were detected by enhanced chemiluminescence (Amersham).

Statistical analyses. The number of experiment replications is given in the figure legends; experiments were conducted with cultures from different seedings. Data were analyzed by Student's $t$ tests for two groups or ANOVA followed by post hoc comparisons for multiple groups with an Instat software package (GraphPad Software, San Diego, CA).

\section{Results}

\section{Traumatic injury activates ERK in cultured astrocytes}

Primary cultures of rat cortical astrocytes grown on deformable SILASTIC membranes were subjected to stretch-induced injury with a pressure pulse duration of $60 \mathrm{msec}$. Uninjured cells in a well of the Flex Plate served as controls. Cultures were returned to the incubator, and $10 \mathrm{~min}$ after injury, cells were lysed, and ERK phosphorylation and activity were determined. As shown in Figure 1, $A$ and $B$, marked increases in ERK1/2 phosphorylation and ERK activity were observed. Inhibition of MAPK/ERK kinase (MEK), the upstream activator of ERK, by U0126 completely blocked the injury-induced phosphorylation and activation of ERK (Fig. $1 A, B$ ). Another MEK inhibitor, PD098059, also diminished injury-induced activation of ERK (percent inhibition = $73.7 \% \pm 6.2$; data not shown). Group data revealed that injury induced a $8.2 \pm 0.8$-fold increase in ERK activity $(n=16 ; p<$ 0.0001 ); by comparison, when uninjured cultures grown on deformable membranes were treated with serum $(10 \%)$ as a positive control, a $13.4 \pm 2.2$-fold increase in ERK activity $(n=5)$ was observed, indicating that activation of ERK by stretch-induced injury was $\sim 60 \%$ of maximal stimulation. To determine the time course of stretch-induced ERK stimulation, ERK activity was measured at various periods after injury. Significant activation of ERK was observed at 1 min after injury, and maximal activation was sustained from 10 to $30 \mathrm{~min}$ (Fig. 2). Injury-induced ERK activity began to decline gradually after $30 \mathrm{~min}$ and remained twofold over basal levels at $3 \mathrm{hr}$. 


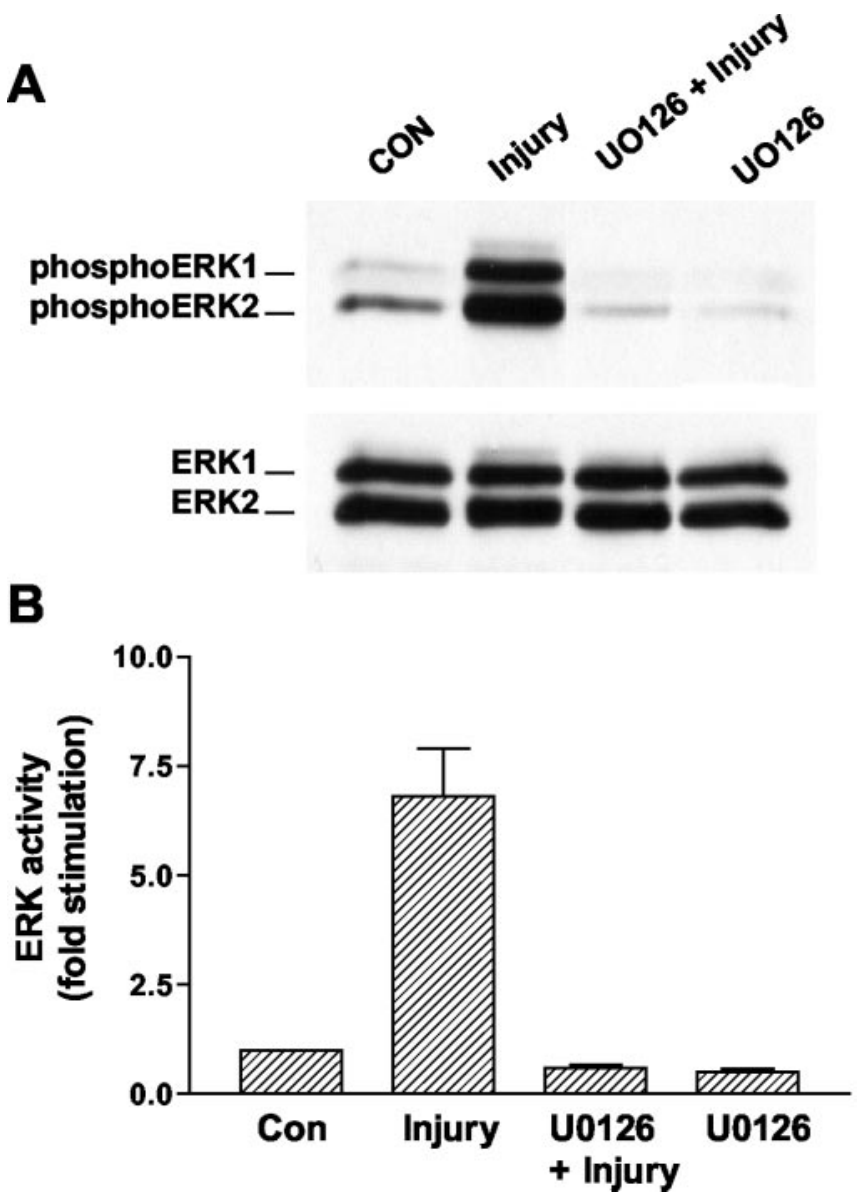

Figure 1. Stretch-induced injury activates ERK, which is inhibited by blocking MEK. Primary cultures of rat cortical astrocytes grown on deformable SILASTIC membranes were subjected to stretch-induced injury (60 msec, $7.5 \mathrm{~mm}$ maximum membrane displacement, 54\% stretch). Cultures were returned to the incubator $\left(37^{\circ} \mathrm{C} ; 95 \%\right.$ air, $\left.5 \% \mathrm{CO}_{2}\right)$, and after $10 \mathrm{~min}$, cells were lysed, and ERK phosphorylation and activity were determined as described in Materials and Methods. Some cultures were treated with U0126 $(10 \mu \mathrm{M})$ for $30 \mathrm{~min}$ before injury. Uninjured cells in a well of the Flex Plate served as controls (CON). In $A$, immunoblots were probed with an antibody that recognizes dually phosphorylated ERK1 and ERK2 (Thr183, Tyr185) (top panel) or an antibody that does not distinguish between phosphorylated or unphosphorylated ERK1,2 (bottom panel). Results are representative of two independent experiments conducted under identical conditions with different culture seedings. In B, ERK activity data were obtained from two experiments and expressed as fold stimulation (mean \pm SEM) compared with controls. ERK activity in uninjured cultures was $202 \pm 73 \mathrm{pmol}$ of phosphate transferred per minute per milligram of protein.

\section{ERK activation is dependent on the rate and magnitude of injury}

To characterize the relationship between traumatic injury and ERK activation, studies were conducted over a range of SILASTIC membrane displacements and rates of displacements. Previous work with this in vitro injury model defined displacements from 5 to $7.5 \mathrm{~mm}$ as mild to severe stretch (Ahmed et al., 2000). This range of membrane displacements corresponds to biaxial strains, or stretch, that are $24-54 \%$ and are relevant to those that occur in humans after rotational acceleration-deceleration injury, as indicated by studies with gel-filled human skulls (Shreiber et al., 1995). Primary cultures of rat cortical astrocytes were subjected to stretch-induced injury for $60 \mathrm{msec}$ at displacements ranging from 3 to $7.5 \mathrm{~mm}$. Cultures were returned to the incubator, and after $10 \mathrm{~min}$, cells were lysed, and ERK phosphorylation and ERK activity were measured. We found that ERK phosphorylation and activity were increased in a graded manner with increasing de-

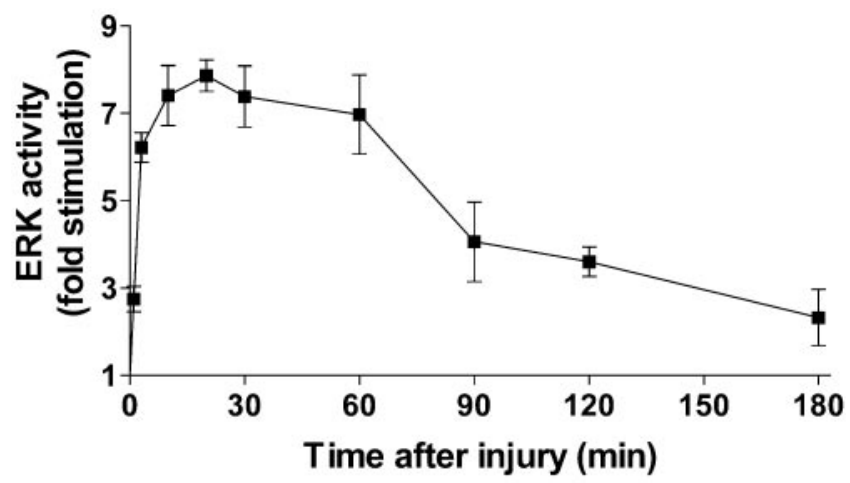

Figure 2. Time course of ERK activation after stretch-induced injury. Primary cultures of rat cortical astrocytes grown on deformable SILASTIC membranes were subjected to stretchinduced injury of $7.5 \mathrm{~mm}$ displacement for $60 \mathrm{msec}$. Cultures were returned to the incubator $\left(37^{\circ} \mathrm{C} ; 95 \%\right.$ air, $\left.5 \% \mathrm{CO}_{2}\right)$, and after the indicated times, cells were lysed and ERK activity was determined as described in Materials and Methods. Uninjured cells in wells of Flex Plates served as controls (CON). ERK activity data were obtained from three experiments and expressed as fold stimulation (mean \pm SEM) compared with controls. ERK activity in uninjured cultures was $106 \pm 15 \mathrm{pmol}$ of phosphate transferred per minute per milligram of protein.

grees of SILASTIC membrane deformation corresponding to mild, moderate, and severe stretch (Fig. 3A,B). To examine the effect of the rate of stretch on ERK stimulation, cells were stretched for pressure pulse durations ranging from 20 to $99 \mathrm{msec}$ with a maximal membrane displacement of $5.5 \mathrm{~mm}$ for all pulse durations. These different durations of injury, with the same degree of stretch, can be achieved by regulating the pulse pressure (Ellis et al., 1995). We found that ERK phosphorylation and activity were maximal from 20 to $60 \mathrm{msec}$ and declined in a graded manner from 80 to $99 \mathrm{msec}$ (Fig. 4A,B). Data analysis revealed that there were no significant differences between injury-induced ERK activities from 20 to $60 \mathrm{msec}$, but ERK activity was significantly reduced at the slowest stretch rate examined ( $p<0.05$ by ANOVA repeated measures). Thus, more ERK activation occurred at faster rates of stretch. Collectively, the results of experiments presented in Figures 3 and 4 demonstrate that activation of ERK is dependent on the degree and rate of stretch.

Injury-induced activation of ERK is dependent on calcium Calcium in astrocytes is increased after traumatic injury both in vivo (Hovda et al., 1992; Fineman et al., 1993) and in vitro (Rzigalinski et al., 1997; Rzigalinski et al., 1998). In addition, calcium is upstream of ERK in some signaling pathways (Dikic et al., 1996). To determine whether calcium plays a role in activation of ERK, calcium influx was diminished by treating astrocytes with EGTA before injury. As shown in Figure 5, this markedly reduced ERK phosphorylation. Group data revealed that chelation of extracellular calcium by EGTA inhibited ERK activation by $84 \%(n=4 ; p<0.05)$. Similarly, injury-induced ERK activation was reduced $71 \%$ by chelation of intracellular calcium with BAPTA-AM (50 $\mu \mathrm{M}, 30 \mathrm{~min}$ before injury; data not shown). These observations demonstrate the importance of calcium in the signaling pathway that leads to ERK activation after mechanical stretch.

\section{Injury-induced ERK activation is attributable in part to} extracellular ATP

ATP is released after tissue injury (Bodin et al., 1992; Bergfeld and Forrester, 1992), and activation of astrocytic P2 purinergic receptors by ATP leads to ERK stimulation (Neary and Zhu, 1994; King et al., 1996; Neary et al., 1999). Because studies with the in vitro 
A
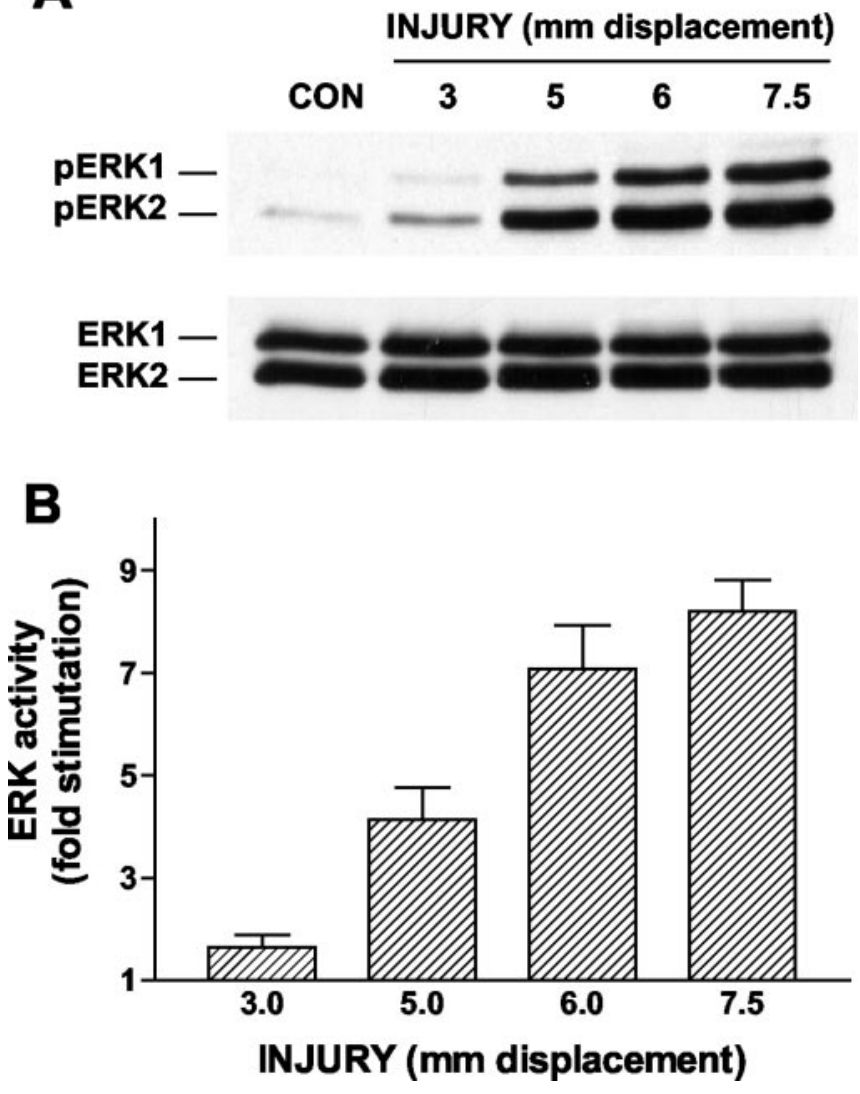

Figure 3. Stretch injury-induced ERK stimulation is dependent on the magnitude of displacement. Primary cultures of rat cortical astrocytes grown on deformable SILASTIC membranes were subjected to stretch-induced injury for $60 \mathrm{msec}$ at displacements ranging from 3 to $7.5 \mathrm{~mm}\left(8-54 \%\right.$ stretch). Cultures were returned to the incubator $\left(37^{\circ} \mathrm{C} ; 95 \%\right.$ air, $\left.5 \% \mathrm{CO}_{2}\right)$, and after $10 \mathrm{~min}$, cells were lysed, and ERK phosphorylation and activity were determined as described in Materials and Methods. Uninjured cells in a well of the Flex Plate served as controls (CON). In A, immunoblots were probed with an antibody that recognizes dually phosphorylated ERK1 and ERK2 (Thr183, Tyr185) (top panel) or an antibody that does not distinguish between phosphorylated or unphosphorylated ERK1,2 (bottom panel). Results are representative of three independent experiments conducted under identical conditions with different culture seedings. In $B$, ERK activity data were obtained from three experiments and expressed as fold stimulation (mean \pm SEM) compared with controls. ERK activity in uninjured cultures was $127 \pm 30$ pmol of phosphate transferred per minute per milligram of protein.

injury model used here have demonstrated that ATP is released from astrocytes after stretch-induced injury (Ahmed et al., 2000), we decided to test the hypothesis that ATP released after injury activates ERK. Two approaches were used to test this hypothesis. First, apyrase, an ATP diphosphohydrolase that metabolizes ATP to AMP, was added to primary cultures of rat cortical astrocytes before injury. Under these conditions of enhanced ATP breakdown, the phosphorylation of ERK induced by injury was reduced (Fig. 6A). ERK activity measurements indicated that addition of apyrase resulted in reductions of $76 \%(n=5 ; p<0.005)$, $51 \%(n=5 ; p<0.005)$, and $38 \%(n=3 ; p<0.01)$ of ERK activity 1,3 , and 10 min after injury, respectively (Fig. $6 B$ ). To test whether the decrease in inhibition over time could be caused by release of more ATP, experiments were conducted at higher apyrase concentrations. Compared with $38 \%$ inhibition $10 \mathrm{~min}$ after injury at $30 \mathrm{U}$ apyrase $/ \mathrm{ml}, 52 \%$ inhibition occurred at $60 \mathrm{U}$ apyrase $/ \mathrm{ml}$, and $75 \%$ inhibition occurred at $90 \mathrm{U}$ apyrase $/ \mathrm{ml}$, thereby suggesting an increase in release of ATP over time. To confirm that apyrase treatment would inhibit activation of ERK
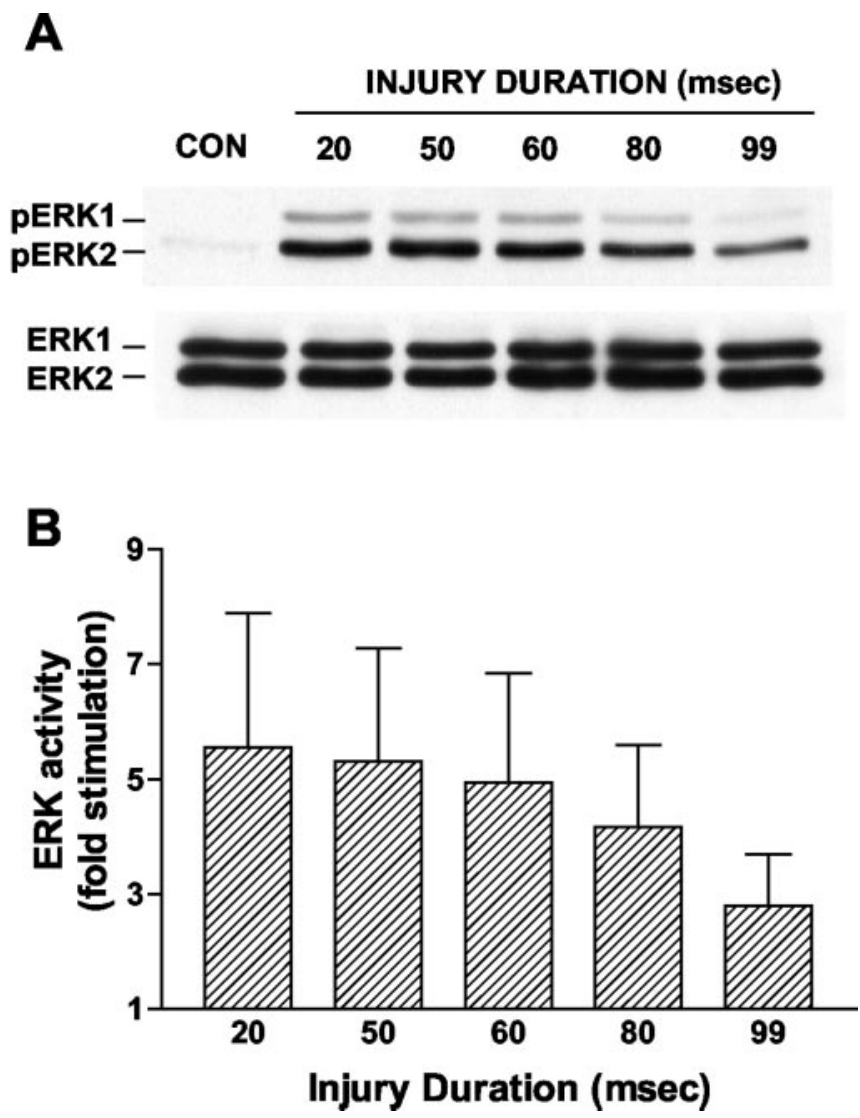

Figure 4. Injury-induced ERK stimulation is dependent on the rate of stretch. Primary cultures of rat cortical astrocytes grown on deformable SILASTIC membranes were subjected to stretch-induced injury at times ranging from 20 to 99 msec; the extent of displacement was maintained at $5.5 \mathrm{~mm}$ by using different pressure pulses for the different times examined. Cultures were returned to the incubator $\left(37^{\circ} \mathrm{C} ; 95 \%\right.$ air, $\left.5 \% \mathrm{CO}_{2}\right)$, and after $10 \mathrm{~min}$, cells were lysed, and ERK phosphorylation and activity were determined as described in Materials and Methods. Uninjured cells in a well of the Flex Plate served as controls (CON). In A, immunoblots were probed with an antibody that recognizes dually phosphorylated ERK1 and ERK2 (Thr183, Tyr185) (top panel) or an antibody that does not distinguish between phosphorylated or unphosphorylated ERK1,2 (bottom panel). Results are representative of three independent experiments conducted under identical conditions with different culture seedings. In $B$, ERK activity data were obtained from four experiments and expressed as fold stimulation (mean \pm SEM) compared with controls. ERK activity in uninjured cultures was $90.5 \pm 19 \mathrm{pmol}$ of phosphate transferred per minute per milligram of protein.

by extracellular ATP, primary cultures of rat cortical astrocytes grown on $35 \mathrm{~mm}$ Petri dishes were treated with apyrase $(30 \mathrm{U} / \mathrm{ml})$ 15 min before addition of ATP $(1 \mu \mathrm{M})$. ERK activity was stimulated $3.90 \pm 0.61$-fold $(n=3)$ by 10 min treatment with ATP $(1$ $\mu \mathrm{M})$ compared with vehicle-treated controls, whereas addition of apyrase almost completely eliminated ERK activation by ATP (percent inhibition $=97.4 \pm 2.6 \%$ ).

In a second approach, suramin, a broad-spectrum antagonist of P2 purinergic receptors (Ralevic and Burnstock, 1998) previously shown to inhibit activation of ERK by extracellular ATP in rat cortical astrocytes (Neary and Zhu, 1994), was added to astrocytes before injury. When $\mathrm{P} 2$ receptors were inhibited, phosphorylation of ERK induced by injury was reduced (Fig. 7A). ERK activity measurements indicated that addition of suramin resulted in reductions in ERK activity of 50\% $(n=3 ; p<0.05)$ and $64 \%(n=3 ; p<0.05) 3$ and 10 min after injury, respectively (Fig. $7 B$ ). Although the difference between each time point and the untreated, injured group was significant, the difference between the extent of inhibition at 3 and 10 min was not statistically sig- 


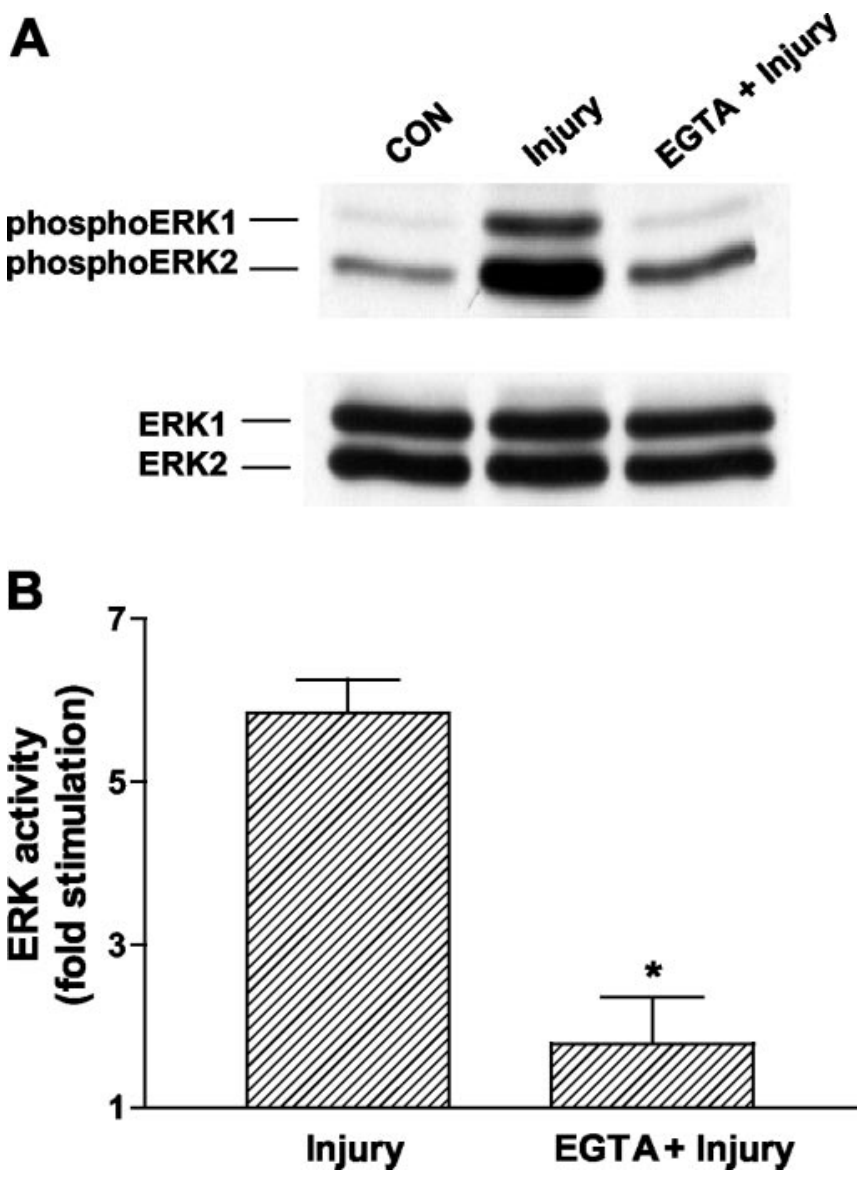

Figure 5. Stretch-induced injury activates ERK by a calcium-dependent pathway. Primary cultures of rat cortical astrocytes grown on deformable SILASTIC membranes were subjected to stretch-induced injury ( $7.5 \mathrm{~mm}$ maximum membrane displacement, $50-60 \mathrm{msec})$. Cultures were returned to the incubator $\left(37^{\circ} \mathrm{C} ; 95 \%\right.$ air, $\left.5 \% \mathrm{CO}_{2}\right)$, and after $10 \mathrm{~min}$, cells were lysed, and ERK phosphorylation and activity were determined as described in Materials and Methods. Some cultures were treated with EGTA $(5 \mathrm{~mm})$ for $5 \mathrm{~min}$ before injury. Uninjured cells in a well of the Flex Plate served as controls (CON). In $A$, immunoblots were probed with an antibody that recognizes dually phosphorylated ERK1 and ERK2 (Thr183, Tyr185) (top panel) or an antibody that does not distinguish between phosphorylated or unphosphorylated ERK1,2 (bottom panel). Results are representative of two independent experiments conducted under identical conditions with different culture seedings. In $B$, ERK activity data were obtained from four experiments and expressed as fold stimulation (mean \pm SEM) compared with controls. ERK activity in uninjured cultures was $89.8 \pm 12.5$ pmol of phosphate transferred per minute per milligram of protein $\left({ }^{*} p<0.05\right)$.

nificant $(p>0.3)$. At a higher suramin concentration $(300 \mu \mathrm{M})$, $78 \%$ inhibition was observed. Taken together, these findings indicate $\sim 75 \%$ of injury-induced ERK activation can be inhibited by breakdown of extracellular ATP or blockade of $\mathrm{P} 2$ receptors.

Injury-induced ERK activation is stimulated by selected P2 receptor subtypes

Two main classes of $\mathrm{P} 2$ receptors have been distinguished, $\mathrm{P} 2 \mathrm{Y}$ (G-protein-coupled receptors) and P2X (ligand-gated ion channel receptors), and seven subtypes of each have been identified (Ralevic and Burnstock, 1998). P2Y1, P2Y2, and P2Y4 subtypes as well as P2X1, P2X2, P2X3, P2X4, P2X6, and P2X7 subtypes are expressed in astrocytes (Lenz et al., 2000; Franke et al., 2001; Kukley et al., 2001). To investigate whether some or all of these subtypes activate ERK in response to the released ATP, we conducted experiments with a series of antagonists for P2X and P2Y receptors (Ralevic and Burnstock, 1998). Injury-induced ERK
A

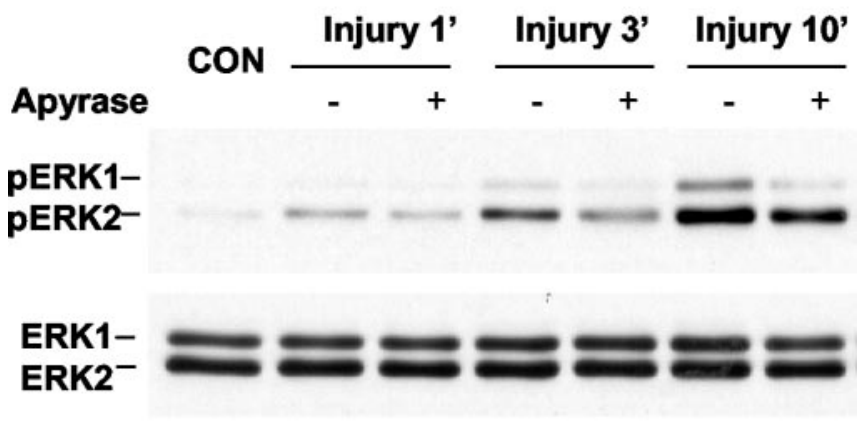

B

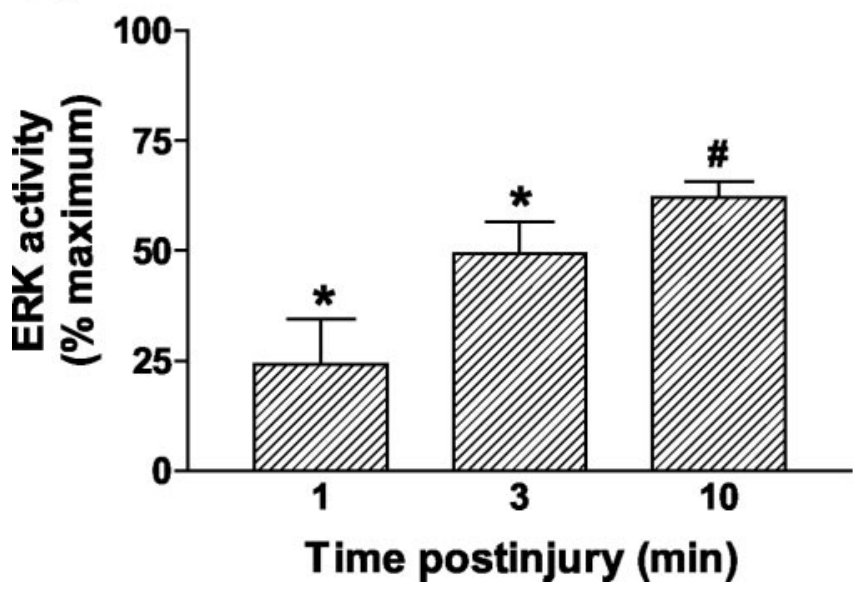

Figure 6. Activation of ERK by traumatic injury is reduced by degradation of extracellular ATP. Primary cultures of rat cortical astrocytes grown on deformable SILASTIC membranes were subjected to stretch-induced injury $(7.5 \mathrm{~mm}$ displacement for $60 \mathrm{msec})$. Some cultures were treated with apyrase ( $30 \mathrm{U} / \mathrm{ml}$; Grade VII, Sigma, St. Louis, MO) for 15 min before injury. Uninjured cells in a well of the Flex Plate served as a control (CON), whereas cells in another well were treated with apyrase $(30 \mathrm{U} / \mathrm{ml})$ but were not injured. Cultures were returned to the incubator $\left(37^{\circ} \mathrm{C} ; 95 \%\right.$ air, $\left.5 \% \mathrm{CO}_{2}\right)$, and cells were lysed after various time periods. ERK phosphorylation and activity were determined as described in Materials and Methods. In $A$, immunoblots were probed with an antibody that recognizes dually phosphorylated ERK1 and ERK2 (Thr183, Tyr185) (top panel) or an antibody that does not distinguish between phosphorylated or unphosphorylated ERK1,2 (bottom panel). Results are representative of three independent experiments conducted under identical conditions with different culture seedings. In $B$, ERK activity data were obtained from three to five experiments and expressed as the percentage of injuryinduced ERK activation (percent maximum; mean \pm SEM) at the different time periods studied. ERK activity in uninjured cultures was $83 \pm 7 \mathrm{pmol}$ of phosphate transferred per minute per milligram of protein; maximum ERK responses expressed as fold stimulation (mean \pm SEM) compared with uninjured cells were $2.15 \pm 0.32,4.72 \pm 0.67$, and $7.19 \pm 1.77$ at 1,3 , and 10 min after injury, respectively ( ${ }^{*} p<0.005 ; \# p<0.01$ ).

activation was reduced $58 \%$ by reactive blue 2 (Fig. $8 \mathrm{~A}$ ), an effective antagonist of P2X2 receptors (King et al., 1997; Swanson et al., 1998). ERK activation was also inhibited by iso-pyridoxal-5' phosphate-6-azophenyl-2',5' disulfonate (iso-PPADS), an antagonist of $\mathrm{P} 2 \mathrm{X} 1, \mathrm{P} 2 \mathrm{X} 2$, or $\mathrm{P} 2 \mathrm{X} 3$ receptors (Fig. 8 A). However, $\mathrm{P} 2 \mathrm{X} 1$ and $\mathrm{P} 2 \mathrm{X} 3$ receptors may not be involved because trinitrophenyl (TNP)-ATP, a potent antagonist of P2X1 and P2X3 receptors (Virginio et al., 1998), did not inhibit ERK activation (Fig. 8A). Moreover, in studies with uninjured astrocytes, $\alpha, \beta$ meATP, a selective agonist of $\mathrm{P} 2 \mathrm{X} 1$ and $\mathrm{P} 2 \mathrm{X} 3$ receptors, did not activate ERK (Fig. $8 \mathrm{~B}$ ). The results of these experiments suggest a role for P2X2 receptors. Both $\mathrm{P} 2 \mathrm{X} 2$ and $\mathrm{P} 2 \mathrm{X} 7$ receptors are linked to ERK (Swanson et al., 1998; Panenka et al., 2001), but we have 
A

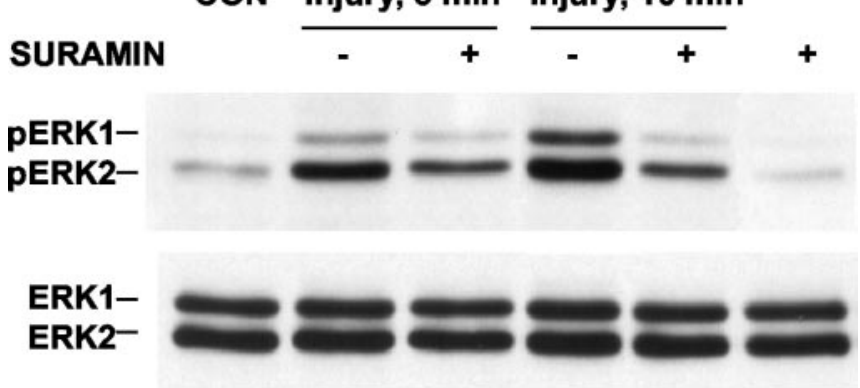

B

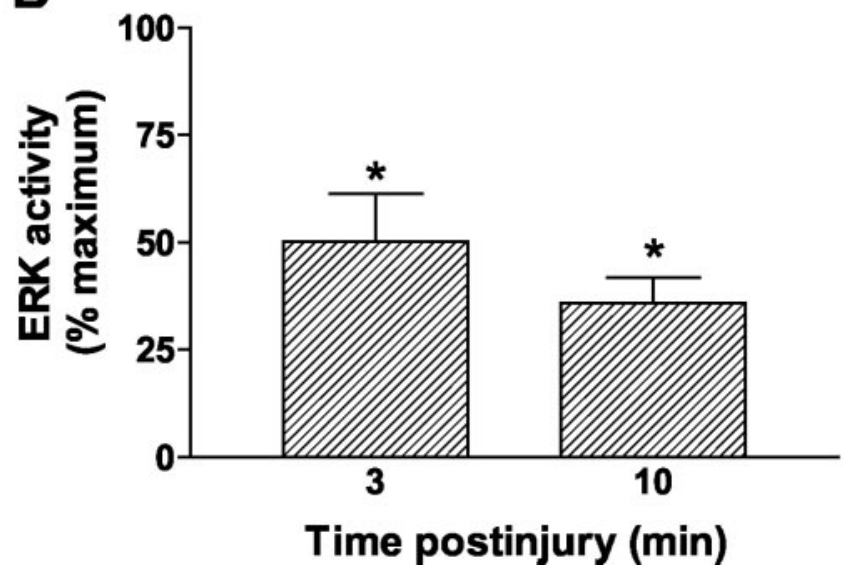

Figure 7. Activation of ERK by traumatic injury is reduced by inhibition of P2 purinergic receptors. Primary cultures of rat cortical astrocytes grown on deformable SILASTIC membranes were subjected to stretch-induced injury $(7.5 \mathrm{~mm}$ displacement for $60 \mathrm{msec})$. Some cultures were treated with suramin (100 $\mu \mathrm{m}$; Sigma) for 15 min before injury. Uninjured cells in a well of the Flex Plate served as a control ( $C O N$ ), whereas cells in another well were treated with suramin $(100 \mu \mathrm{M})$ but were not injured. Cultures were returned to the incubator $\left(37^{\circ} \mathrm{C} ; 95 \%\right.$ air, $5 \%$ $\left(\mathrm{O}_{2}\right)$, and cells were lysed after various time periods. ERK phosphorylation and activity were determined as described in Materials and Methods. In $A$, immunoblots were probed with an antibody that recognizes dually phosphorylated ERK1 and ERK2 (Thr183, Tyr185) (top panel) or an antibody that does not distinguish between phosphorylated or unphosphorylated ERK1,2 (bottom panel). Results are representative of two independent experiments conducted under identical conditions with different culture seedings. In $B$, ERK activity data were obtained from three experiments and expressed as the percentage of injury-induced ERK activation (percent maximum; mean $\pm \mathrm{SEM}$ ) at the different time periods studied. ERK activity in uninjured cultures was $105 \pm 29.5 \mathrm{pmol}$ of phosphate transferred per minute per milligram of protein; maximum ERK responses expressed as fold stimulation (mean \pm SEM) compared with uninjured cells were $3.43 \pm 0.95$ and $6.99 \pm 2.47$ at 3 and 10 min after injury, respectively $\left({ }^{*} p<\right.$ $0.05)$.

found that brilliant blue $\mathrm{G}$, a potent and selective antagonist for P2X7 receptors (Jiang et al., 2000), did not inhibit injury-induced ERK activation (Fig. $8 \mathrm{~A}$ ). The effectiveness of brilliant blue $\mathrm{G}$ in antagonizing $\mathrm{P} 2 \mathrm{X} 7$ receptors was confirmed by experiments in uninjured astrocytes where activation of ERK by $3^{\prime}-O-(4-$ benzoylbenzoyl(Bz)ATP, a P2X7 agonist, was inhibited 70\% by brilliant blue $\mathrm{G}$ (Fig. 8 B). In addition, a role for P2Y1 receptors was indicated because a selective antagonist of P2Y1 receptors, $N^{6}$-methyl 2'-deoxyadenosine 3',5'-bisphosphate (MRS-2179) (Boyer et al., 1998), inhibited 24\% of injury-induced ERK activation (Fig. 8A). Combined treatment with reactive blue 2 and MRS-2179 reduced ERK activation by $72 \%$ (data not shown). Thus, these studies point to a role for P2X2 and P2Y1 receptors, but not P2X1, P2X3, and P2X7 receptors, in injury-induced ERK activation.
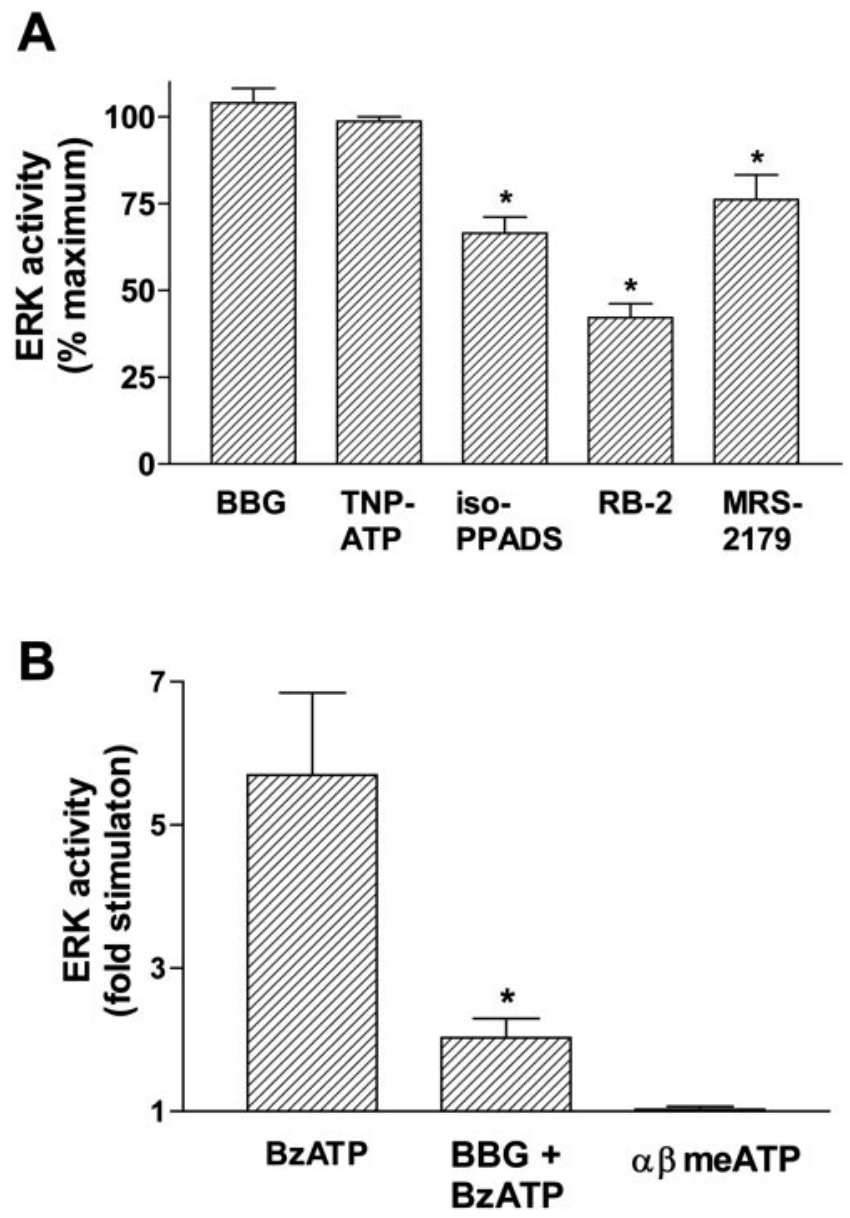

Figure 8. Selective activation of $\mathrm{P} 2$ receptors coupled to ERK by injury-induced release of ATP. Primary cultures of rat cortical astrocytes grown on deformable SILASTIC membranes were subjected to stretch-induced injury ( $7.5 \mathrm{~mm}$ displacement for $50 \mathrm{msec})$. In $A$, some cultures were treated with brilliant blue $G(B B G, 1 \mu \mathrm{m})$, TNP-ATP $(1 \mu \mathrm{M})$, iso-PPADS $(50 \mu \mathrm{m})$, reactive blue 2 (RB-2, $50 \mu \mathrm{M})$, or MRS-2179 $(100 \mu \mathrm{m})$ for 5-15 min before injury (antagonists were obtained from Sigma). Uninjured cells in a well of the Flex Plate served as a control. Cultures were returned to the incubator $\left(37^{\circ} \mathrm{C} ; 95 \%\right.$ air, $\left.5 \% \mathrm{CO}_{2}\right)$, and cells were lysed $10 \mathrm{~min}$ after injury. ERK activity was determined as described in Materials and Methods. ERK activity data were obtained from a total of 15 experiments and expressed as the percentage of injury-induced ERK activation (percent maximum; mean \pm SEM) within each experiment. ERK activity in uninjured cultures was $78.3 \pm 12.7$ pmol of phosphate transferred per minute per milligram of protein; maximum ERK response expressed as fold stimulation (mean \pm SEM) compared with uninjured cells was $9.78 \pm 1.15\left({ }^{*} p<0.05\right)$. In $B$, ERK activity was determined in uninjured primary astrocyte cultures grown on $35 \mathrm{~mm}$ plates. Cells were treated with BzATP (100 $\mu \mathrm{M})$, brilliant blue $G(B B G, 1 \mu \mathrm{m})$ for 15 min before addition of BzATP $(100 \mu \mathrm{m})$, or $\alpha, \beta$-meATP $(30 \mu \mathrm{m})$. Ten minutes after addition of agonists, cells were lysed, and ERK activity was determined as described in Materials and Methods. ERK activity data were obtained from five experiments and expressed as fold stimulation (mean \pm SEM) compared with controls. ERK activity in uninjured cultures was $115 \pm 15 \mathrm{pmol}$ of phosphate transferred per minute per milligram of protein. Similar results were obtained with 10 and $100 \mu \mathrm{m} \alpha, \beta$-meATP (data not shown).

\section{Discussion}

The main findings of the studies presented here are that (1) stretch-induced injury activates ERK in primary cultures of rat cortical astrocytes by a calcium-dependent pathway and (2) injury-induced ERK activation is attributable in part to extracellular ATP released after injury and activation of selected types $\mathrm{P} 2 \mathrm{X}$ and $\mathrm{P} 2 \mathrm{Y}$ purinergic receptors.

The dependence of injury-induced ERK activation on the extent and rate of stretch described here parallels characteristics of cell injury previously described for this in vitro model of trau- 
matic injury (Ellis et al., 1995). Ellis et al. (1995) used propidium iodide uptake and lactate dehydrogenase release to study astrocyte injury with this in vitro model. They found that as astrocytes were exposed to increasing degrees of stretch, increasing numbers of cells sequestered propidium iodide, thereby indicating increasing membrane permeability and cellular injury. Lactate dehydrogenase release was also proportional to the extent of cell stretch, with maximum release occurring within $2 \mathrm{hr}$ of injury. In addition, injury as assessed by dye uptake was greater at faster rates of stretch than at slower rates. However, after stretch most cells regained their ability to exclude propidium iodide and no further release of lactate dehydrogenase occurred after $24 \mathrm{hr}$, thereby indicating that injured astrocytes are capable of repair. Consistent with this, morphological studies did not detect evidence of cell lysis. Our findings that ERK activity was increased in a graded manner with increasing degrees of stretch and that rapid stretch brought about more ERK activation than slower stretch are in good agreement with changes in stretch-induced cell injury. These results suggest that ERK stimulation occurs at displacements and rates of stretch that are relevant to human traumatic brain injury because biomechanical acceleration-deceleration studies have demonstrated that the degrees of strain and the rates of stretch used here occur in gel-filled human skulls (Shreiber et al., 1995).

Members of the MAPK family play an important role in transduction of mechanical forces. The effects of mechanical stimulation on MAPK activation appear to depend on the cell type. For example, ERK was activated by stretch in retinal capillary pericytes (Suzuma et al., 2002) and cardiac tissue (Takeishi et al., 2001; Domingos et al., 2002). However, ERK was not activated by either repetitive (Nguyen et al., 2000) or sustained (Kushida et al., 2001) stretch in rat bladder smooth muscle cells, but other MAPKs (c-Jun $\mathrm{NH}_{2}$-terminal kinase and p38) were activated. To our knowledge, the evidence presented here represents the first report of stretch-induced ERK activation in astrocytes. Previous studies have shown that stretch-induced injury in astrocytes leads to increases in intracellular calcium (Rzigalinski et al., 1997, 1998), activation of phospholipases (Lamb et al., 1997; Floyd et al., 2001), and free radical formation (McKinney et al., 1996). These signaling elements have been linked to ERK pathways in some systems (Dikic et al., 1996; Fialkow et al., 1994), and our results demonstrate a role for calcium because chelation of extracellular calcium with EGTA or chelation of intracellular calcium with BATPA-AM markedly reduced injury-induced ERK activation. This finding supports and extends the importance of calcium in traumatic injury.

The role of extracellular ATP and stimulation of P2 receptors in stretch-induced ERK activation in astrocytes have been investigated in the studies reported here. ATP is released from a variety of cells by mechanical stimulation, fluid shear stress, and other means of membrane perturbations (Bodin et al., 1991; Grierson and Meldolesi, 1995; Sprague et al., 1998; Ostrom et al., 2000). These reports demonstrate that ATP is readily released from endothelial or epithelial tissues that are subjected to shear flow or distension. Although the brain is normally protected from mechanical stimulation, it has been shown that ATP is released from astrocytes and neurons after stretch-induced injury in the model of brain trauma used in our studies (Ahmed et al., 2000). Evidence presented here indicates that extracellular ATP contributes to the activation of ERK by mechanical stretch. First, stretchinduced ERK activation was significantly reduced by breakdown of extracellular ATP. Second, inhibition of P2 purinergic receptors also resulted in a significant decrease in stretch-induced ERK activity. Studies with a series of $\mathrm{P} 2$ receptor antagonists suggest a role for P2X2 and P2Y1 receptors because injury-induced ERK activation was inhibited by reactive blue 2 and iso-PPADS, effective antagonists of P2X2 receptors (King et al., 1997; Swanson et al., 1998), and by MRS-2179, an effective antagonist of P2Y1 receptors (Boyer et al., 1998). The greater inhibition by reactive blue 2 compared with iso-PPADS or MRS-2179 may be caused by antagonism of additional P2 receptors such as P2Y4 (Bogdanov et al., 1998). P2X1, P2X3, and P2X7 receptors are expressed on astrocytes but are not likely to be involved because antagonists known to block these subtypes (Virginio et al., 1998; Jiang et al., 2000) did not inhibit injury-induced ERK activation. However, other subtypes expressed on astrocytes cannot be excluded at this time. For example, reactive blue 2 is an effective antagonist of $\mathrm{P} 2 \mathrm{Y} 6$ and $\mathrm{P} 2 \mathrm{Y} 12$ receptors as well as $\mathrm{P} 2 \mathrm{X} 2$ receptors and is a weaker antagonist of P2X3, P2Y4, and P2Y11 receptors (Burnstock, 2002). RT-PCR and functional studies have demonstrated that P2Y6, P2Y11, and P2Y12 are not expressed on rat cortical astrocytes in culture (Lenz et al., 2000), but the potential involvement of P2Y4 and another purine-pyrimidine-preferring receptor, $\mathrm{P} 2 \mathrm{Y} 2$, as well as $\mathrm{P} 2 \mathrm{X} 4$ and $\mathrm{P} 2 \mathrm{X} 6$ receptors, remains to be determined.

Because breakdown of extracellular ATP or inhibition of P2 receptor activation did not completely reduce ERK activation, other mechanisms may also be involved. Previous studies have demonstrated that transduction of mechanical forces involves integrins and the actin cytoskeleton that are linked to ERK (for review, see Alenghat and Ingber, 2002). For example, cytoskeletal destabilization appears to be a causative factor in stretch-induced ERK activation in mesangial cells (Ingram et al., 2000; Dlugosz et al., 2000). Thus, it is tempting to speculate that integrin-cytoskeleton interactions may also play a role in stretch-induced ERK activation in astrocytes, either coupled directly to ERK or indirectly via P2 purinergic receptors (Erb et al., 2001), but further studies are needed to explore these possibilities. Nonetheless, the studies reported here provide the first evidence for a role of extracellular ATP and P2 purinergic receptors in stretch-induced ERK activation.

These findings may have implications for the development of gliosis after brain trauma. An important response of astrocytes to brain injury is reactive astrocytosis which leads to formation of the glial scar (Dietrich et al., 1999 and references therein). Gliosis is frequently believed to be detrimental to nerve regeneration because reactive astrocytes can produce regeneration-inhibitory molecules such as proteoglycans (Snow et al., 1990; McKeon et al., 1991). However, reactive astrocytes also secrete growth factors and express adhesion molecules that may promote cell survival and nerve regeneration (for review, see Eddleston and Mucke, 1993; Ridet et al., 1997). Gliosis is characterized by the formation and elongation of astrocytic processes, increased glial fibrillary acidic protein, an astrocyte-specific intermediate filament protein, and cellular proliferation. These hallmarks of gliosis can be induced by addition of ATP or ATP analogs to cultured astrocytes or injection into rat brains (Rathbone et al., 1992; Neary and Norenberg, 1992; Neary et al., 1994a,b, 1998; Abbracchio et al., 1994; Bolego et al., 1997; Franke et al., 1999). Inhibition of the ERK cascade greatly diminishes these trophic actions of extracellular ATP (Neary et al., 1998, 1999; Brambilla et al., 2002), thereby indicating the importance of this signaling pathway in the development of reactive astrocytosis. The studies reported here implicate a role for extracellular ATP, P2 purinergic receptors, and calcium-dependent ERK signaling in the response of astrocytes to injury, thereby providing the basis for a 
detailed investigation of the upstream signaling components and the downstream targets of injury-induced ERK activation. It will be of interest to determine whether activation of P2X and P2Y receptor/ERK signaling pathways by traumatic injury underlies the expression of astrocytic proteins that inhibit or promote nerve regeneration.

\section{References}

Abbracchio MP, Saffrey MJ, Hopker V, Burnstock G (1994) Modulation of astroglial cell proliferation by analogues of adenosine and ATP in primary cultures of rat striatum. Neuroscience 59:67-76.

Ahmed SM, Rzigalinski BA, Willoughby KA, Sitterding HA, Ellis EF (2000) Stretch-induced injury alters mitochondrial membrane potential and cellular ATP in cultured astrocytes and neurons. J Neurochem 74:1951-1960.

Alenghat FJ, Ingber DE (2002) Mechanotransduction: all signals point to cytoskeleton, matrix, and integrins. Science STKE 119:PE6.

Bergfeld GR, Forrester T (1992) Release of ATP from human erythrocytes in response to a brief period of hypoxia and hypercapnia. Cardio Res 26:40-47.

Bodin P, Bailey DJ, Burnstock G (1991) Increased flow-induced ATP release from isolated vascular endothelial but not smooth muscle cells. Br J Pharmacol 103:1203-1205.

Bodin P, Milner P, Winter R, Burnstock G (1992) Chronic hypoxia changes the ratio of endothelin to ATP release from rat aortic endothelial cells exposed to high flow. Proc R Soc Lond B Biol Sci 247:131-135.

Bogdanov YD, Wildman SS, Clements MP, King BF, Burnstock G (1998) Molecular cloning and characterization of rat $\mathrm{P}_{2} \mathrm{Y}_{4}$ nucleotide receptor. Br J Pharmacol 124:428-430.

Bolego C, Ceruti S, Brambilla R, Puglisi L, Cattabeni F, Burnstock G, Abbracchio MP (1997) Characterization of the signalling pathways involved in ATP and basic fibroblast growth factor-induced astrogliosis. Br J Pharmacol 121:1692-1699.

Boyer JL, Mohanram A, Camaioni E, Jacobson KA, Harden TK (1998) Competitive and selective antagonism of $\mathrm{P}_{2} \mathrm{Y}_{1}$ receptors by $\mathrm{N}^{6}$-methyl 2'-deoxyadenosine 3', 5'-bisphosphate. Br J Pharmacol 124:1-3.

Brambilla R, Neary JT, Cattabeni F, Cottini L, D’Ippolito G, Schiller P, Abbracchio MP (2002) Induction of COX-2 and reactive gliosis by P2Y receptors in rat cortical astrocytes is dependent on ERK1/2 but independent of calcium signaling. J Neurochem 83:1285-1296.

Burnstock G (2002) ATP and its metabolites as potent extracellular agonists. In: Purinergic receptors and signaling, (Schwiebert EM, ed). San Diego: Academic.

Dietrich WD, Alonso O, Halley M (1994) Early microvascular and neuronal consequences of traumatic brain injury: a light and electron microscopic study in rats. J Neurotrauma 11:289-301.

Dietrich WD, Treuttner J, Zhao W, Alonso OF, Busto R, Ginsberg MD (1999) Sequential changes in glial fibrillary acidic protein and gene expression following parasagittal fluid-percussion brain injury in rats. J Neurotrauma 16:567-581.

Dikic I, Tokiwa G, Lev S, Courtneidge SA, Schlessinger J (1996) A role for Pyk2 and Src in linking G-protein-coupled receptors with MAP kinase activation. Nature 383:547-550.

Dlugosz JA, Munk S, Kapor-Drezgic J, Goldberg HJ, Fantus IG, Scholey JW, Whiteside CI (2000) Stretch-induced mesangial cell ERK1/ERK2 activation is enhanced in high glucose by decreased dephosphorylation. Am J Physiol Renal Physiol 279:F688-F697.

Domingos PP, Fonseca PM, Nadruz Jr W, Franchini KG (2002) Loadinduced focal adhesion kinase activation in the myocardium: role of stretch and contractile activity. Am J Physiol Heart Circ Physiol 282:H556-H564.

Eddleston M, Mucke L (1993) Molecular profile of reactive astrocytes: implications for their role in neurologic disease. Neuroscience 54:15-36.

Ellis EF, McKinney JS, Willoughby KA, Liang S, Povlishock JT (1995) A new model for rapid stretch-induced injury of cells in culture: characterization of the model using astrocytes. J Neurotrauma 12:325-339.

Erb L, Liu J, Ockerhausen J, Kong Q, Garrad RC, Griffin K, Neal C, Krugh B, Santiago-Peréz LI, González FA, Gresham HD, Turner JT, Weisman GA (2001) An RGD sequence in the $\mathrm{P} 2 \mathrm{Y}_{2}$ receptor interacts with $\alpha_{\mathrm{V}} \beta_{3}$ integrins and is required for $\mathrm{G}_{\mathrm{o}}$-mediated signal transduction. J Cell Biol 153:491-501.

Fialkow L, Chan CK, Rotin D, Grinstein S, Downey GP (1994) Activation of mitogen activated protein kinase signaling pathway in neutrophils: role of oxidants. J Biol Chem 269:31234-31242.

Fineman I, Hovda DA, Smith M, Yoshino A, Becker DP (1993) Concussive brain injury is associated with a prolonged accumulation of calcium: a ${ }^{45} \mathrm{Ca}$ autoradiographic study. Brain Res 624:94-102.

Floyd CL, Rzigalinski BA, Weber JT, Sitterding HA, Willoughby KA, Ellis EF (2001) Traumatic injury of cultured astrocytes alters inositol $(1,4,5)$ trisphosphate-mediated signaling. Glia 33:12-23.

Franke H, Krügel U, Illes P (1999) P2 receptor-mediated proliferative effects on astrocytes in vivo. Glia 28:190-200.

Franke H, Grosche J, Schädlich H, Krügel U, Allgaier C, Illes P (2001) P2X receptor expression on astrocytes in the nucleus accumbens of rats. Neuroscience 108:421-429.

Grierson JP, Meldolesi J (1995) Shear stress-induced $\left[\mathrm{Ca}^{2+}\right]$ i transients and oscillations in mouse fibroblasts are mediated by endogenously released ATP. J Biol Chem 270:4451-4456.

Hovda DA, Becker DP, Katayama Y (1992) Secondary injury and acidosis. J Neurotrauma 9[Suppl 1]:S47-S60.

Ingram AJ, James L, Cai L, Thai K, Ly H, Scholey JW (2000) NO inhibits stretch-induced MAPK activity by cytoskeletal disruption. J Biol Chem 275:40301-40306.

Jiang L-H, Mackenzie AB, North RA, Surprenant A (2000) Brilliant Blue G selectively blocks ATP-gated rat $\mathrm{P} 2 \mathrm{X}_{7}$ receptors. Mol Pharmacol 58:82-88.

King BF, Neary JT, Zhu Q, Wang S, Norenberg MD, Burnstock G (1996) P2 purinoceptors in rat cortical astrocytes: expression, calcium-imaging and signalling studies. Neuroscience 74:1187-1196.

King BF, Wildman SS, Ziganshina LE, Pintor J, Burnstock G (1997) Effects of extracellular $\mathrm{pH}$ on agonism and antagonism at a recombinant $\mathrm{P} 2 \mathrm{X} 2$ receptor. Br J Pharmacol 121:1445-1453.

Kukley M, Barden JA, Steinhauser C, Jabs R (2001) Distribution of P2X receptors on astrocytes in juvenile rat hippocampus. Glia 36:11-21.

Kushida N, Kabuyama Y, Yamaguchi O, Homma Y (2001) Essential role for extracellular $\mathrm{Ca}^{2+}$ in JNK activation by mechanical stretch in bladder smooth muscle cells. Am J Physiol Cell Physiol 281:C1165-C1172.

Laemmli UK (1970) Cleavage of structural proteins during the assembly of the head of bacteriophage T4. Nature 227:680-685.

Lamb RG, Harper CC, McKinney JS, Rzigalinski BA, Ellis EF (1997) Alterations in phosphatidylcholine metabolism of stretch injured cultured rat astrocytes. J Neurochem 68:1904-1910.

Lenz G, Gottfried C, Luo Z, Avruch J, Rodnight R, Nie W-J, Kang Y, Neary JT (2000) $\mathrm{P}_{2 \mathrm{Y}}$ purinoceptor subtypes recruit different MEK activators in astrocytes. Br J Pharmacol 129:927-936.

Marguiles SS, Thibault LE, Gennarelli TA (1990) Physical model simulations of brain injury in the primate. J Biomech 23:823-836.

McIntosh TK (1992) Pharmacological strategies in the treatment of experimental brain injury. J Neurotrauma 9 [Suppl 1]:S201-S209.

McKeon RJ, Schreiber RC, Rudge JS, Silver J (1991) Reduction of neurite outgrowth in a model of glial scarring following CNS injury is correlated with the expression of inhibitory molecules on reactive astrocytes. J Neurosci 11:3398-3411.

McKinney JS, Willoughby KA, Liang S, Ellis EF (1996) Stretch-induced injury of cultured neuronal, glial, and endothelial cells. Stroke 27:934-940.

Neary JT, Norenberg MD (1992) Signalling by extracellular ATP: physiological and pathological considerations in neuronal-astrocytic interactions. Prog Brain Res 94:145-151.

Neary JT, Zhu Q (1994) Signaling by ATP receptors in astrocytes. Neuro Report 5:1617-1620.

Neary JT, Baker L, Jorgensen SL, Norenberg MD (1994a) Extracellular ATP induces stellation and increases GFAP content and DNA synthesis in primary astrocyte cultures. Acta Neuropathol 87:8-13.

Neary JT, Whittemore SR, Zhu Q, Norenberg MD (1994b) Synergistic activation of DNA synthesis in astrocytes by fibroblast growth factor and extracellular ATP. J Neurochem 63:490-494.

Neary JT, McCarthy M, Kang Y, Zuniga S (1998) Mitogenic signaling from $\mathrm{P} 1$ and $\mathrm{P} 2$ purinergic receptors to mitogen-activated protein kinase in human fetal astrocytes. Neurosci Lett 242:159-162.

Neary JT, Kang Y, Bu Y, Yu E, Akong K, Peters CM (1999) Mitogenic signaling by ATP/P2Y purinergic receptors in astrocytes: involvement of a calcium-independent protein kinase $\mathrm{C}$, extracellular signal regulated protein kinase pathway distinct from the phosphatidylinositol-specific phospholipase C, calcium pathway. J Neurosci 19:4211-4220.

Nguyen HT, Adam RM, Bride SH, Park JM, Peters CA, Freeman MR (2000) 
Cyclic stretch activates p38 SAPK2-, ErbB2-, and AT1-dependent signaling in bladder smooth muscle cells. Am J Physiol Cell Physiol 279:C1155-C1167.

Ostrom RS, Gregorian C, Insel PA (2000) Cellular release of and response to ATP as key determinants of the set-point of signal transduction pathways. J Biol Chem 275:11735-11739.

Panenka W, Jijon H, Herx LM, Armstrong JN, Feighan D, Wei T, Yong VW, Ransohoff RM, MacVicar BA (2001) P2X7-like receptor activation in astrocytes increases chemokine monocyte chemoattractant protein- 1 expression via mitogen-activated protein kinase. J Neurosci 21:7135-7142.

Peterson GL (1983) Determination of total protein. Methods Enzymol 91:95-119.

Ralevic V, Burnstock G (1998) Receptors for purines and pyrimidines. Pharmacol Rev 50:413-492.

Rathbone MP, Middlemiss PJ, Kim J-L, Gysbers JW, DeForge SP, Smith RW, Hughes DW (1992) Adenosine and its nucleotides stimulate proliferation of chick astrocytes and human astrocytoma cells. Neurosci Res 13:1-17.

Ridet JL, Malhotra SK, Privat A, Gage FH (1997) Reactive astrocytes: cellular and molecular cues to biological function. Trends Neurosci 20:570-577.

Rzigalinski BA, Liang S, McKinney JS, Willoughby KA, Ellis EF (1997) Effect of $\mathrm{Ca}^{2+}$ on in vitro astrocyte injury. J Neurochem 68:289-296.

Rzigalinski BA, Weber JT, Willoughby KA, Ellis EF (1998) Intracellular free calcium dynamics in stretch-injured astrocytes. J Neurochem 70:2377-2385.

Sevetson BR, Kong X, Lawrence Jr JC (1993) Increasing cAMP attenuates activation of mitogen-activated protein kinase. Proc Natl Acad Sci USA 90:10305-10309.

Shreiber D, Gennarelli TA, Meaney DF (1995) International Research Council on Biokinetics of Impact. Proceedings of the 1995 International Research Conference on Biomechanics of Impact. Brunen, Switzerland, September.

Snow DM, Lemmon V, Carrino DA, Caplan AI, Silver J (1990) Sulfated proteoglycans in astroglial barriers inhibit neurite outgrowth in vitro. Exp Neurol 109:111-130.

Sprague RS, Ellsworth ML, Stephenson AH, Kleinhenz ME, Lonigro AJ (1998) Deformation-induced ATP release from red blood cells requires CFTR activity. Am J Physiol Heart Circ Physiol 275:H1726-H1732.

Suzuma I, Suzuma K, Ueki K, Hata Y, Feener EP, King GL, Aiello LP (2002) Stretch-induced retinal vascular endothelial growth factor expression is mediated by phosphatidylinositol 3-kinase and protein kinase $\mathrm{C}$ (PKC)- $\zeta$ but not by stretch-induced ERK1/2, Akt, Ras or classical/novel PKC pathways. J Biol Chem 277:1047-1057.

Swanson KD, Reigh C, Landreth GE (1998) ATP-stimulated activation of the mitogen-activated protein kinases through ionotropic $\mathrm{P} 2 \mathrm{X} 2$ purinoceptors in PC12 cells. Difference in purinoceptor sensitivity in two PC12 cell lines. J Biol Chem 273:19965-19971.

Takeishi Y, Huang Q, Abe J, Glassman M, Che W, Lee JD, Kawakatsu H, Lawrence EG, Hoit BD, Berk BC, Walsh RA (2001) Src and multiple MAP kinase activation in cardiac hypertrophy and congestive heart failure under chronic pressure-overload: comparison with acute mechanical stretch. J Mol Cell Cardiol 33:1637-1648.

Thibault LE, Meaney DF, Anderson BJ, Marmarou A (1992) Biomechanical aspects of a fluid percussion model of brain injury. J Neurotrauma 9:311-322.

Virginio C, Robertson G, Surprenant A, North RA (1998) Trinitrophenylsubstituted nucleotides are potent antagonists selective for P2X1, P2X3 and heteromeric P2X2/3 receptors. Mol Pharmacol 53:969-973.

Wei EP, Lamb RG, Kontos HA (1982) Increased phospholipase C activity after experimental brain injury. J Neurosurg 56:695-698.

Zhang L, Rzigalinski BA, Ellis EF, Satin LS (1996) Reduction of voltagedependent $\mathrm{Mg}^{2+}$ blockade of NMDA current in mechanically injured neurons. Science 274:1921-1923. 